\title{
A PILOT STUDY OF OVER-EDUCATION IN HONG KONG
}

\author{
TILO LI, ANDY CHAN, EUGENE LI
}

\begin{abstract}
:
Over-education has long been an issue among developed economies in the western world for decades. Researchers have conducted studies and estimated the ratio of over-education of their respective countries; however, there was not much done, if any, for Hong Kong. The purposes of this study are: first, to estimate the proportion of over-education in Hong Kong; second, to compare differences across different demographic factors including majors of studies, years of work experience, income levels, academic qualification levels, industries, and gender.
\end{abstract}

The data set consists of 279 respondents. The subjective (self-reported) over-education rate for current job is 34.1 percent. At the 0.05 significance level, the population proportion, or overall subjective over-education rate in Hong Kong is estimated at between 28.54 percent and 39.66 percent. The sample proportion of objective over-education, measured by the excess of highest qualification over minimum requirement for the current job, is 49.1 percent. At the 0.05 significance level, the population proportion of objective over-education is estimated to be between 43.23 percent and 54.97 percent. The correlation between subjective and objective over-education is 0.342 . It is not a very strong positive relationship, but it is significant $(p=0.000)$. Differences between the two are also significant $(p=0.000)$. While over-education appears to be a serious issue, the sample shows an objective under-education rate of 2.5 percent.

Overall, differences of demographic factors are mostly insignificant, but multiple comparisons among sub-groups for subjective over-education have found that medicine, dentistry and health majors are significantly different from other majors.

Results of this study will narrow the research gap for Hong Kong on over-education. It also opens the door for future research and deeper study concerning over-education in Hong Kong between graduates of government-funded and privately-funded higher education institutes, across different majors and industries. These will not only have substantial financial implications on government spending on higher education but also provide directions for students' choices.

\section{Keywords:}

Over-education in Hong Kong, Cross-demographic differences in over-education, subjective versus objective over-education

JEL Classification: $121, \mathrm{H} 52$

\section{Authors:}

TILO LI, Tung Wah College, Hong Kong, Email: tiloli@twc.edu.hk ANDY CHAN, Tung Wah College, Hong Kong, Email: andychan@twc.edu.hk EUGENE LI, The Hong Kong University of Science and Technology, Hong Kong, Email: Iceugene@ust.hk 


\section{Citation:}

TILO LI, ANDY CHAN, EUGENE LI (2018). A pilot study of over-education in Hong Kong. International Journal of Teaching and Education, Vol. VI(1), pp. 1-20., 10.20472/TE.2018.6.1.001 


\section{INTRODUCTION}

Over-education refers to the situation that workers have higher academic qualification, or more years of education, or more skills than their jobs require. Over-education is also termed as over-qualification. It started as early as 1970's in the United States (Duncan \& Hoffman, 1981). The situation has become worse among developed economies including the United Kingdom (Chevalier \& Lindley, 2008), member countries of the Organisation for Economic Co-operation and Development (“OECD”) (Quintini, 2011). About 21 percent of workers in OECD countries reported that their academic qualifications were higher than their jobs required (Davos-Klosters, 2014). In particular, the over-education rates for first jobs in Italy, Spain, and the United Kingdom are 23 percent, 17 percent, and 14 percent, respectively. Over-education in the United States appears to be more serious than OCED member countries (Caroleo \& Pastore, 2015); it stands at about 48 percent ( $\mathrm{Li}$, Malvin, \& Simonson, 2015). In Japan, it stands at 27.13 percent, with the hardest hit in science and mathematics majors that record a 36.21 percent over-education (Kucel, Molina \& Raya, 2016). In China, due to the rapid economic development in the last few decades, over-education has also become an issue. The number of graduates has increased from one million to over five million per year from 2002 to 2010. While the demand for graduate workers has increased, concerns about whether the increase in demand could absorb the dramatic increase in the supply of graduates (Shen and Kuhn, 2012).

Over-education and job-skills mismatch seem to be common among developed economies. Hong Kong cannot be immune from it. How do graduates feel if they have fallen into the "college trap" (Vance, 2014)? A "college trap" occurs when a person's thought of college education would provide better career opportunities, and he/she went for it. The person had borrowed student loans, spent money, time, and effort on earning a degree, but that turned out to be not helpful in his/her career.

The aim of this research is to raise the public's attention regarding over-education as a growing social issue in Hong Kong. The supply of degree jobs is less than the number of graduates. Therefore, the traditional Chinese wisdom "golden house in books" may not be true, and in reality the human-capital theory does not necessarily apply to every graduate. Irrelevant degrees do not help individuals' careers. Degree holders who are unable to find jobs relevant to their majors need to accept jobs that require lower academic qualifications. This job-qualification mismatch is a typical over-education situation. This generates a huge economic cost, and it possibly creates potential social costs as well.

This paper will firstly discuss the current higher education situation of Hong Kong, followed by a literature review of over-education. Methodology of data collection and results will then be discussed. A conclusion section will end the paper.

\section{THE HONG KONG SITUATION}

The higher education structure of Hong Kong has been changed dramatically since the former Chief Executive Tung Chee Hwa in 2000 set a policy objective to provide higher education places to 60 percent of secondary school-leavers (Tung, 2000). The higher education sector has changed from an "ivory tower" to a mass education system (Mok, 2007) or a universal system (Wan, 2011). 
While the supply of government-funded higher education places has grown steadily, self-financed higher education places have mushroomed rapidly bypassing the optimal with excess supply. Substantial excess supply of 3,603 higher education places began in the academic year 2005/2006 (University Grants Committee of Hong Kong, 2010), and it peaked in 2013/2014 with an excess supply of 6,222 places (Li, 2015). Excess supply of higher education places will continue to worsen due to two reasons. From the demand side, secondary school student population is shrinking due to low birth rate. From the supply side, private higher education institutes are creating more and more new programs and providing more and more places. Self-financing degree programs have grown from 41 in 2006/7 to 135 in 2015/16; top-up degree programs have grown from 55 in 2008/9 to 199 in 2015/16 (Education Bureau, 2017)

Hong Kong has reached a point where whoever meets the minimum admission requirements must have a place to go for his/her bachelor's degree education. Competition among students for government-funded education places is still severe, but competition for self-financed places is minimal except for some popular professionallydriven programs such as nursing and occupational therapy. Programs of arts and humanities, social sciences are hit badly.

The supply of degree graduates has increased rapidly. With an annual addition of about 40,000 fresh graduates entering the workforce (Legislative Council Secretariat, 2016), the question is: do we have an equivalent increase in jobs absorbing the increase in degree holders? Do books still contain "golden houses"? Are graduates able to find qualification-matching jobs? This leads to the first research question: What is the overeducation situation in Hong Kong?

According to Legislative Council Secretariat (2016), from 1994 to 2015 a total of 854,000 new degree holders were added to the workforce while the increase in degree holder jobs was 666,000; an excess supply of 188,000 (or 22 percent) degree holders assuming unrealistically that all other degree holders were able to find qualificationmatching jobs. The excess supply of degree holders over the 20-year period was averaged at 9,400 per year.

According to the latest Hong Kong Poverty Situation Report 2016 (Census and Statistics Department, 2017), among the 165,800 working poor population, a total of 28,300 (17 percent) hold post-secondary qualifications, among which 17,000 (10.2 percent) of them hold a post-secondary degree. The number of working poor degree holders increased from 9,300 in 2012 (Census and Statistics Department, 2013) to 17,000 in 2016 (Census and Statistics Department, 2017), an increase of over 80 percent. Working poor includes those earning less than 50 percent of the median income. This echoes the Legislative Council Secretariat (2015) report that education has not led to better job prospects.

Resources are limited; government spending of tax money is tight almost everywhere in the world. The Hong Kong government's expenditure on post-secondary education for the year 2015-16 was estimated at HK\$21.68 billion (Education Bureau, 2016). One percent of over-education means HK\$216.8 million being misallocated. The Hong Kong government is still running a surplus budget. However, the surplus will not last forever. When the government runs a budget deficit, we will need to face funding cuts. If the government spending does not create its value, our government will need to find alternatives to create better value and results of its money spent. At student level, 
having spent four years on average to earn a bachelor's degree, do they get qualification-matching jobs? Will graduates earn enough to cover their education cost? If students neither get qualification-matching jobs nor upward mobility, they will need to rethink how they will invest their time and money for their future career.

Hong Kong used to provide ample opportunities to graduates with a lot of chances for them to move up the social ladder. However, with the rapid increase in graduates, the increase in high-end jobs has not been able to catch up. Degree holders do not have the same kind of upward mobility as their counterpart generations ago. The Legislative Council Secretariat (2015) concludes that higher education has not led to better job prospects. This creates negative sentiments against the society and the government. Social mobility is an important factor of social harmony.

Is the Chinese traditional wisdom of "golden house in books" still true? Does higher education bring better jobs and higher pay so as to provide better living? Answers to these questions are important to justify billions of education dollars that governments spend in addition to students spending on tuitions and giving up their incomes. Resources are limited. If government dollars are spent without creating the corresponding values, the money should have been spent on areas that create more value for the society. If students' tuition payments do not warrant expected higher incomes, they will need to reconsider where to invest their money and efforts for a better future. More importantly, graduates who are unable to find qualification-matching jobs develop all kinds of negativities leading to different levels of social unrest.

With a better understanding of the different over-education situations across different demographic factors, students will be able to make a better choice should they decide to study for a bachelor's degree program. This leads to the second research question: are there differences in over-education across different demographic factors such as majors, qualification levels, and industries.

\section{OVER-EDUCATION}

Academics suggest different reasons for over-education. Freeman (1976) alleges that government subsidies in higher education can cause over-supply of highly educated workers. Economic theories suggest that education provides external benefits to societies. Students normally consider their private benefits from education. Without incorporating external benefits into the total benefits of education, it is a market failure. Government subsidies on education can correct this by shifting the private demand for education to the right to become the social demand for education leading to a higher social equilibrium price and quantity (Frank, Bernanke, \& Antonovics, 2017). Whether government should subsidize education is debatable.

Human Capital Theory in labor economics suggests that people have the same human capital and should be remunerated equivalently. Wage differentials can be due to factors such as shift duty, work environment and conditions, vacation leave, and other benefits. Human capital includes superficially a set of knowledge, abilities and skills that can be learned and acquired through education and training (Borjas, 2016). This can be quantified by the number of years of schooling. However, as other researchers (Storen and Arnesen, 2016; Verhaest and Van der Velden, 2013) point out that there are differences in the quality of programs offered by different institutions. This results in skills heterogeneity; Bachelor of Arts issued by different institutes carries different 
qualities. In the workplace, human capital includes also work experience, communication skills, work attitude, inter-personal relationship, and personal connections. These soft skills may not be easily educated, trained, and quantified.

Borjas (2016) points out that human capital accumulation is affected by a number of socioeconomic and innate factors. Socioeconomic or environmental factors refer to, among others, family background, parental skills, race and ethnicity, peer influence and neighborhood. Innate factors are inborn. Some people are born smarter; people are born with different abilities.

The most tempting reason for over-education is certainly wage premiums. Li, Malvin, and Simonson (2015) find that in the United States the median earning for bachelor degree holders between 25 and 34 years old in 2010 was 2.14 times employees with high school qualification. In Hong Kong in 2013, the median monthly employment income of a degree holder was HK\$25,000, while the median income of average workers was HK\$13,000 (Legislative Council Secretariat, 2015).

Another reason for over-education is that job applicants having a higher academic qualification have more chances of being contacted for an interview by Chinese employers (Shen \& Kuhn, 2012). Shen and Kuhn (2012) find that Chinese firms tend to favor over-qualified applicants, but foreign firms tend to favor appropriate-qualified applicants. They further find that master graduates are far more likely to be overqualified.

These reasons match the traditional belief that master's degrees and doctorates are the way to wealth (Vance, 2014), and it echoes the traditional Chinese wisdom of "golden house in books". This of course only applies to employed degree holders. What about the educated unemployed?

Other reasons for over-education include information asymmetries and institutional characteristics of the labor market (Bender \& Heywood, 2011); people seek for higher academic qualifications at times of high unemployment (Pascual Saez, GonzalezPrieto, \& Cantarero-Prieto, 2016); graduates enter the labor market at the time of recession when there are insufficient qualification-matching jobs (Verhaest and Van der Velden, 2013); young people accept lower requirement jobs due to lack of experience (Frei \& Sousa-Poza, 2012); time lag in education training the necessary skills versus industry demands; people planning to migrate to another country can seek for higher academic qualification; and highly qualified immigrants who are unable to find qualification-matching jobs (Quintini, 2011).

Does higher qualification lead to higher skills and more employability? This is not necessarily the case because there are imperfections in the measurement of educational skills, and grades from different colleges mean differently (Frei \& SousaPoza, 2012). An " $A$ " student of the University of Hong Kong is different from an " $A$ " student of $X Y Z$ College down the road. Some individuals could be wrongly labeled as over-educated. Some people could have gone for higher education purely due to personal interest; employability is not an issue to them.

Quintini (2011) states that over-qualification does not necessarily mean over-skilled. Is this due to credential inflation or skills/qualification heterogeneity? At the longitudinal level, in recent decades, with massive increase in the supply of degree places and substantial increase in student enrollment in different levels of degree programs, do students graduate with the same quality as compared with their counterpart generations 
ago when degree places were very limited?

It is generally believed that grades do not carry the same quality as before due to grade inflation (Babcock, 2010; Henderson, 2011; Kariya, 2011; Kuhn, Warren, Maletta, \& Branford, 2011; Sadler, 2009; Smith \& Fleisher, 2011; Qiang \& Wolff, 2009). Borjas (2016) even alleges that a large proportion of high school graduates are functionally illiterate; there is no systematic relationship between government funding on education and student performance.

At the sectional level, graduates with the same degree from different institutes can have different skills (Borjas, 2016; Storen \& Arnesen, 2016). "Those who are formally overeducated just lack the necessary skills" (Verhaest \& Van Der Velden, 2013, P. 648). This occurs especially in countries where colleges/universities are vertically stratified (Marginson, 2017). That is to say, there are tiers or rankings of colleges/universities within a country.

In an earlier work, Robst (1995) points out that individuals might have graduated from colleges of different quality. Actually, college quality is a crucial factor to determine if a person is over-educated. People who have attended a high-quality college have a lower probability of being over-educated. This is consistent with findings of Verhaest and Van Der Velden (2013) whose study covers 13 European countries and Japan. They also find that the major of study is another important contributing factor to over-education. Storen and Arnesen (2016) find that humanities and social sciences graduates tend to have less chances to utilize their skills acquired from their studies leading to a higher chance of being over-educated.

There are contradicting results if over-education and productivity are positively correlated. Vermeylen and Giuliano (2014) find a positive relationship, while Vance (2014) argues that there is no direct relationship. Borjas (2016) alleges that schooling may not necessarily increase the productivity of a person, but it provides a "signal" that a person having gone to a good school, having obtained more or higher education "signals" that the person could afford expensive education and be presumably smarter. It is generally believed that a doctorate degree holder should be smarter than a high school dropout.

Vance (2014) finds that in terms of per-capita productivity, the United States is higher than South Korea, Japan, and Canada, but these countries have a higher college completion rate than the United States. On the contra, the United States has lower percapita productivity than Switzerland and Singapore, but the former has a higher college completion rate than the latter.

Vance (2014) points out that higher education hurts the poor. Those who do not have the right background have very little chance for upward social mobility even though they have earned a college degree. Those who cannot afford higher education are excluded from job selection process simply because there are too many degree holder applicants. The situation in the United States is that a lot of college graduates do not have qualification-matching jobs, but they need to repay a huge student loan. For people without a degree, they are stuck in their low-incoming jobs without much chance for moving upward socially.

Higher education does not necessarily make upward social mobility easier. Whether a graduate can move up the social ladder depends on family background, the major of studies, and the ranking of the university. Simply a degree granted from an ABC institute 
and a general degree do not guarantee job opportunities. Having said that, does it mean students should not seek for higher education? The answer may be "no" because if anyone does not have a degree while everyone else has one, the person will have no chance (Marginson, 2017; Mok, 2016). The result, and the current situation is that "the massification of higher education has intensified inequality in education and positional competition among graduates" (Mok, 2016, P. 64). Higher education actually hinders upward social mobility resulting from massification of higher education. The positional arms races theory in Economics (Frank, Bernanke, \& Antonovics, 2017) can explain this phenomenon. Accelerating investment on education by individuals offsets one another. For those who can afford higher education, they may neither become advantageous nor have a better chance. On the other hand, for those who cannot afford it, they become disadvantageous and have no chance.

While over-qualification is a common phenomenon among advanced economies, Klosters (2014) reports that in Europe, about 40 percent of employers having difficulties in finding workers with the required skills. Young people and workers are ill-prepared for work. American factories are hungry for skilled workers (Vance, 2014). Therefore, major-job mismatch is another socioeconomic issue in these countries.

It will be a political suicide for any government to cut funding on higher education. However, government can gradually educate people having a bachelor's degree is not the only way towards a bright future. Billions of higher education dollars can be reallocated from funding degree programs to vocational training programs. Germany has been very successful in promoting vocational education. It has comparatively better youth employment and upward mobility (Vance, 2014). With more appropriate training suitable for career, there will be more room for upward social mobility and that is a crucial factor to the creation of social harmony (Legislative Council Secretariat, 2015). With more people having jobs related to their training and earning income deemed appropriate to their education or vocational training, productivity at the macro level will also be increased.

At student level, having spent four years on average to earn a bachelor's degree plus the forgone income, the economic cost for students to earn a bachelor's degree is substantial. More importantly, psychological negativities developed among overeducated workers are much worse. They are dissatisfied with their jobs. There is little social mobility for them. This in turn creates their "perception of equality of opportunities, and by extension, the fairness of the society as a whole. With doubts about social justice, they may become frustrated and critical of society and governance" (Legislative Council Secretariat, 2015, p. 9). Job dissatisfaction can cause different kinds of psychological problems thereby increasing various family and social issues.

Whether over-qualification (or over-education) in general has a lasting effect for individuals is still inconclusive. It has been found using American data that overqualification tends to be short-lived for those who have attended high-quality colleges, but long-lived for those who have attended low-quality colleges (Robst, 1995; Rubb, 2003). In Switzerland, Frei and Sousa-Poza (2012) find that over-qualification tends to be transitory. It occurs among freshmen who lack experience. Once they have accumulated sufficient experience, they will seek for qualification matching jobs, and most of them are successful in doing so. Therefore, the issue really is the quality of education. In the next section, the methodology of data collection will be discussed. 


\section{METHODOLOGY}

The population includes all workers in Hong Kong holding at least a sub-degree qualification. The minimum sample size is set at 264 adopted from Linda, Marchal and Wathen (2018, P.306), taking the population proportion 0.22 of over-supply of degree holders published by the Legislative Council Secretariat (2016) as over-education, with 0.95 confidence and 0.05 margin of error. Calculation of the minimum sample size is given below:

$$
\text { Minimum sample size }=0.22 \times(1-0.22) \times\left(\frac{1.96}{0.05}\right)^{2}
$$

To answer the first research question: What is the over-education situation of Hong Kong. A total of 279 questionnaires were collected via Google Forms. The population proportions of subjective (self-reported) and objective over-education are estimated based on the sample proportions using the following formula (Linda, Marchal, \& Wathan, 2018, P. 301).

$$
\begin{aligned}
& \text { Confidence interval for a population proportion }=p \pm z \sqrt{\frac{p(1-p)}{n}} \\
& \begin{aligned}
\text { Where: } & p=\text { sample proportion } \\
z & =\text { standard normal value ( } 1.96 \text { for a } 0.05 \text { significance level) } \\
n & =\text { sample size ( } 279 \text { in this case) }
\end{aligned}
\end{aligned}
$$

To answer the second research question: are there differences in over-education across different demographic factors such as major of studies, years of work experience, education levels, income levels, industries, and genders. The major classifications in this study follow the classifications of the University Grants Committee. The industry classifications follow the Census and Statistics Department's classification. One-way ANOVA is done to compare overall differences for each factor, and Post Hoc tests are done to provide comparisons for differences among the subgroups of these factors.

\section{RESULTS AND DISCUSSION}

Among the 279 respondents, 246 of them work full-time, 15 part-time, and 18 selfemployed. The majors of their first sub-degree/degree are distributed as follows: Arts and Humanities (12.5\%), Business and Management (58.1\%), Education (1.1\%), Engineering and Technology (9.3\%), Medicine, Dentistry and Health (5\%), Sciences $(5.4 \%)$, and Social Sciences (8.6\%). Most of them have earned their first degree in Hong Kong (82.1\%); others have earned their degree in Australia (2.5\%), Canada $(3.6 \%)$, mainland China (1.4\%), Taiwan (0.4\%), the United Kingdom (2.5\%), and the United States (7.2\%). The highest academic qualifications are distributed as: Doctoral degree $(2.5 \%)$, Master's degree plus professional qualification $(0.4 \%)$, Master's degree $(21.9 \%)$, post-graduate diploma $(2.5 \%)$, Bachelor's degree plus professional qualification $(0.4 \%)$, Bachelor's degree $(57.7 \%)$, Associate degree/higher diploma $(11.5 \%)$, other post-secondary/professional qualification (3.2\%). As for genders, female and male respondents are 44.8 percent and 49.8 percent respectively, with 5.4 percent missing value.

To answer the first research question, according to the data collected $(n=279)$, the selfreported (or subjective) over-education rate for current job is 34.1 percent. At the 0.05 significance level, the population proportion, or overall subjective over-education rate in 
Hong Kong is estimated at between 28.54 percent and 39.66 percent. This is higher than the OECD average (Davos-Klosters, 2014), but it is close to Japan (Kucel, Molina \& Raya, 2016). This perhaps is due to cultural differences. Europeans are relatively more respectful of blue-collar jobs; Asians tend to rate white-collar jobs as superior to blue-collar jobs. As a result, Europeans are relatively more willing to go for vocational, technical skills training than academic training.

The sample proportion of objective over-education for the current job is 49.1 percent. At the 0.05 significance level, the population proportion, or overall objective over-education rate in Hong Kong is estimated at between 43.23 percent and 54.97 percent. This is far higher than the subjective over-education rate. This objective rate is taken by comparing a respondent's highest academic qualification versus his/her reported minimum academic requirement for his/her current job. Interestingly, an objective, undereducation rate was found at 2.5 percent.

These ratios of subjective and objective over-education are far higher than the oversupply of graduates (22\%) reported by the Legislative Council Secretariat (2016). The report only measured the aggregate total supply and demand without looking at different majors and industries. It explains partially, if not all, the difference. Over-education can be a result of major-job mismatch (Zhu, 2014).

Among the 7 (out of 279 respondents) objective under-education cases, most of them have over 5 years work experience; 3 out of the 7 meet the academic requirement but need to obtain professional qualification; 2 of them are associate degree/higher diploma holders but on degree holder jobs, but they have over 8 years of work experience. It is apparent that employers consider their work experience to compensate for the insufficient academic qualification. Besides, some higher diploma qualifications earned years back were considered as equivalent to bachelor's degree. Higher diploma qualifications nowadays are widely considered as sub-degree. However, when Hong Kong had only two universities before the 1990s, a lot of three-year higher diploma programs required A-levels. Therefore, higher diploma qualifications earned in those eras were considered as equivalent to bachelor's degree and accepted as meeting Master's degree entrance requirement. Therefore, under-education is not quite an issue.

Paired samples T-test was run for the correlation between subjective and objective overeducation. The correlation between the two is 0.342 . It is not a very strong positive relationship, but it is significant $(p=0.000)$. The paired-differences between subjective and objective over-education are significant $(p=0.000)$.

It is not surprising to see a difference between subjective and objective over-education. The former is self-reported, a self-assessment of respondent's own knowledge and skills for his/her current job; while the latter is a comparison between a respondent's highest academic qualification and the minimum requirement for his/her current job. Respondents might find their knowledge and skills learned from extra education have made them more competitive, helped them secure the job, supplemented their knowledge and skills acquired from previous qualifications. They simply want to increase and strengthen their human capital so that they can become more competitive. Therefore, objective over-education is not quite an issue as long as there is no subjective over-education. 
Another notably point is that among those who have had subjective over-education on their last job, 37.5 percent of them are able to find qualification-matching job. Therefore, over-education can be transitory depending on degree quality (Frei \& Sousa-Poza, 2012; Robst, 1995; Rubb, 2003).

To answer the second research questions if there are differences in over-education for different demographic factors, one-way ANOVA and Post Hoc Tests for each demographic factor were run for the following hypothesis:

Null hypothesis: there is no difference in over-education

Alternate hypothesis: there is difference in over-education

The following paragraphs report differences in subjective and objective over-education across majors, education levels, years of work experience, income levels, industries, and genders. The short form "OE" is used to denote over-education and "UE" for undereducation.

Subjective and objective over-/under-education across different first-degree majors are given in Table 1 below:

Table 1: Subjective-Objective Over-/under-Education Across Majors

\begin{tabular}{|l|c|c|c|}
\hline $\begin{array}{l}\text { Major of Studies (first } \\
\text { degree) }\end{array}$ & Subjective OE & Objective OE & Objective UE \\
\hline Arts \& Humanities & $34.3 \%$ & $42.9 \%$ & $5.7 \%$ \\
\hline Business \& Management & $38.3 \%$ & $50.6 \%$ & $1.9 \%$ \\
\hline Education & $33.3 \%$ & $33.33 \%$ & $0 \%$ \\
\hline Engineering \& Technology & $23.1 \%$ & $42.3 \%$ & $3.8 \%$ \\
\hline $\begin{array}{l}\text { Medicine, Dentistry } \\
\text { Health }\end{array}$ & $0 \%$ & $71.4 \%$ & $0 \%$ \\
\hline Sciences & $33.3 \%$ & $45.8 \%$ & $4.2 \%$ \\
\hline Social Sciences & $34.1 \%$ & $49.1 \%$ & $2.5 \%$ \\
\hline Overall & & $46.7 \%$ & $0 \%$ \\
\hline
\end{tabular}

For medicine, dentistry and health majors, there is no subjective over-education, while the objective over-education is the highest at 71.4 percent. Graduates of these majors probably feel the excess academic preparation has prepared them with more advanced knowledge and better skills for their profession so that they can handle their jobs easier. Therefore, they do not find themselves over-educated. Both subjective and objective over-education are high among sciences majors, and business and management 
majors. For engineering and technology majors, while both ratios are below average, the difference in subjective and objective over-education is the second largest.

Overall differences across majors for subjective over-education ( $p=0.118$ ) and objective over-education ( $p=0.532$ ) are insignificant. However, when multiple comparisons among sub-groups for subjective over-education are done, medicine, dentistry and health majors are significantly different from arts and humanities majors $(p=0.022)$, business and management majors $(p=0.004)$, sciences majors $(p=0.023)$, and social sciences majors $(p=0.036)$. So, medicine, dentistry and health majors view differently the excess of their academic qualification over the minimum requirement. For objective over-education, medicine, dentistry and health majors are only marginally, significantly different from arts and humanities majors $(p=0.049)$.

The results here show a pattern that professionally-driven majors tend to have less subjective over-education. The overall workforce tends to have higher academic qualification than the minimum requirement.

Subjective and objective over-/under-education across different education levels are given in Table 2 below:

Table 2: Subjective-Objective OE/UE Across Different Education Levels

\begin{tabular}{|l|c|c|c|}
\hline $\begin{array}{l}\text { Highest Academic } \\
\text { Qualification }\end{array}$ & $\begin{array}{c}\text { Subjective } \\
\text { OE }\end{array}$ & Objective OE & Objective UE \\
\hline Doctoral degree & $28.6 \%$ & $57.1 \%$ & $0 \%$ \\
\hline Master's degree & $30.6 \%$ & $67.7 \%$ & $0 \%$ \\
\hline Post-graduate diploma & $14.3 \%$ & $71.4 \%$ & $0 \%$ \\
\hline Bachelor's degree & $38.9 \%$ & $44.4 \%$ & $1.9 \%$ \\
\hline $\begin{array}{l}\text { Associate degree/higher } \\
\text { diploma }\end{array}$ & $25.0 \%$ & $43.8 \%$ & $9.4 \%$ \\
\hline $\begin{array}{l}\text { Other post-secondary, } \\
\text { Professional qualification }\end{array}$ & $22.2 \%$ & $0 \%$ & $11.1 \%$ \\
\hline Overall & $34.1 \%$ & $49.1 \%$ & $2.5 \%$ \\
\hline
\end{tabular}

The results across different education levels are interesting. For subjective overeducation, bachelor's degree holders have the highest at 38.9 percent. As respondent qualification increases (decreases) to master's (sub-degree), the subjective overeducation rate decreases to 30.6 percent (25.0 percent). For objective over-education, if post-graduate diploma is excluded due to its small sample size and unclear standard, master's degree holders have the highest objective over-education rate. This is similar to findings of Shen and Kuhn (2012). 
Overall differences across different education levels for subjective over-education are insignificant $(p=0.414)$, but it is significant $(p=0.000)$ for objective over-education. Multiple comparisons among sub-groups for objective over-education find that other post-secondary or professional qualification holders are significantly different from all other groups. Master's degree holders are significantly different from associate degree/higher diploma holders $(p=0.004)$, and bachelor's degree holders $(p=0.002)$.

Subjective over-education, objective over-education and objective under-education across different work experience groups are given in Table 3 below:

Table 3: Subjective-Objective Over-/under-Education Across Work Experience

\begin{tabular}{|l|c|c|c|}
\hline Years of Work Experience & Subjective OE & Objective OE & Objective UE \\
\hline Less than 2 years & $41.2 \%$ & $45.6 \%$ & $0 \%$ \\
\hline 2 to less than 5 years & $42.2 \%$ & $51.1 \%$ & $2.2 \%$ \\
\hline 5 to less than 8 years & $37.5 \%$ & $53.1 \%$ & $6.3 \%$ \\
\hline 8 to less than 15 years & $30.5 \%$ & $51.2 \%$ & $3.7 \%$ \\
\hline Over 15 years & $20.0 \%$ & $46 \%$ & $2.0 \%$ \\
\hline Overall & $34.1 \%$ & $49.1 \%$ & $2.5 \%$ \\
\hline
\end{tabular}

Subjective over-education among different years of work experience shows a negative correlation. As the years of work experience increase, the ratio of subjective overeducation drops. There is no obvious pattern for objective over-education.

Overall differences among different work-experience groups for subjective overeducation $(p=0.150)$ and objective over-education $(p=0.999)$ are insignificant. However, multiple comparisons for subjective over-education have found that graduates with over 15 years of work experience are significantly different from the less than 2 years group ( $p=0.017)$, and the 2 to less than 5 years group $(p=0.023)$. A reason for the higher subjective over-education from the less experienced groups is probably because they do not have sufficient work experience so that they accept a lower level job. As Frei and Sousa-Poza (2012) point out that fresh graduates without relevant work experience tend to accept lower qualification-requirement jobs.

Subjective over-education, objective over-education and objective under-education across different income groups are given in Table 4 below: 
Table 4: Subjective-Objective Over-/under-Education Across Income

\begin{tabular}{|l|c|c|c|}
\hline Monthly Income & Subjective OE & Objective OE & Objective UE \\
\hline HK\$9,999 and below & $28.6 \%$ & $42.9 \%$ & $0 \%$ \\
\hline HK\$10,000 - HK\$14,999 & $46.0 \%$ & $44.0 \%$ & $2.0 \%$ \\
\hline HK\$15,000 - HK\$19,999 & $38.0 \%$ & $52.0 \%$ & $0 \%$ \\
\hline HK\$20,000 - HK\$24,999 & $40.5 \%$ & $45.9 \%$ & $5.4 \%$ \\
\hline$H K \$ 25,000-H K \$ 29,999$ & $41.4 \%$ & $51.7 \%$ & $3.4 \%$ \\
\hline$H K \$ 30,000-H K \$ 34,999$ & $33.3 \%$ & $50.0 \%$ & $3.3 \%$ \\
\hline$H K \$ 35,000-H K \$ 39,999$ & $18.8 \%$ & $43.8 \%$ & $0 \%$ \\
\hline$H K \$ 40,000$ and above & $18.3 \%$ & $53.3 \%$ & $3.3 \%$ \\
\hline Overall & $34.1 \%$ & $49.1 \%$ & $2.5 \%$ \\
\hline
\end{tabular}

Although there is no obvious pattern for subjective and objective over-education across different income groups, there is a vague negative relationship between subjective overeducation and income. As income level increases, the subjective over-education ratio decreases. The drop is obvious from the HK\$30,000 - HK\$34,999 group to the $\mathrm{HK} \$ 35,000-\mathrm{HK} \$ 39,999$ group.

Overall differences across different income level groups for subjective over-education $(p=0.064)$ and objective over-education $(p=0.978)$ are insignificant. However, multiple comparisons among sub-groups for subjective over-education have found that graduates with monthly income above $\mathrm{HK} \$ 40,000$ are significantly different from the groups earning $H K \$ 10,000-H K \$ 14,999(p=0.002)$, HK\$15,000- HK\$19,999 ( $p=$ $0.029), H K \$ 20,000-H K \$ 24,999(p=0.024)$, and HK\$25,000 - HK\$29,999 ( $p=0.031)$.

The findings across income groups echo the differences among different work experience groups. Years of work experience and income levels are positively related $(r=0.584)$, and the relationship is significant $(p=0.000)$.

Subjective over-education, objective over-education and objective under-education across different industries are given in Table 5 below: 
Table 5: Subjective-Objective Over-/under-Education Across Industries

\begin{tabular}{|c|c|c|c|}
\hline Industries & $\begin{array}{l}\text { Subjective } \\
\text { OE }\end{array}$ & Objective OE & Objective UE \\
\hline $\begin{array}{l}\text { Accommodation \& Food } \\
\text { Services }\end{array}$ & $66.7 \%$ & $66.7 \%$ & $0 \%$ \\
\hline $\begin{array}{l}\text { Extraterritorial organizations \& } \\
\text { bodies }\end{array}$ & $100 \%$ & $100 \%$ & $0 \%$ \\
\hline $\begin{array}{l}\text { Administration \& support } \\
\text { service }\end{array}$ & $45.0 \%$ & $45.0 \%$ & $5.0 \%$ \\
\hline Agriculture, forestry \& fishing & $0 \%$ & $0 \%$ & $0 \%$ \\
\hline Arts, entertainment \& recreation & $50.0 \%$ & $75.0 \%$ & $0 \%$ \\
\hline Construction & $50.0 \%$ & $66.7 \%$ & $0 \%$ \\
\hline Education & $17.0 \%$ & $35.8 \%$ & $0 \%$ \\
\hline Financial \& insurance & $38.1 \%$ & $45.2 \%$ & $2.4 \%$ \\
\hline Human health \& social work & $29.2 \%$ & $66.7 \%$ & $4.2 \%$ \\
\hline $\begin{array}{l}\text { Import/export, wholesale \& } \\
\text { retail }\end{array}$ & $52.2 \%$ & $47.8 \%$ & $0 \%$ \\
\hline Information \& communications & $27.3 \%$ & $36.4 \%$ & $0 \%$ \\
\hline Manufacturing & $25.0 \%$ & $41.7 \%$ & $0 \%$ \\
\hline $\begin{array}{l}\text { Professional, scientific \& } \\
\text { technical }\end{array}$ & $15.8 \%$ & $47.4 \%$ & $15.8 \%$ \\
\hline Public administration & $100 \%$ & $66.7 \%$ & $0 \%$ \\
\hline Real estate & $22.2 \%$ & $44.4 \%$ & $11.1 \%$ \\
\hline $\begin{array}{l}\text { Transportation, storage, postal } \\
\text { \& courier services }\end{array}$ & $57.1 \%$ & $71.4 \%$ & $0 \%$ \\
\hline Others & $37.8 \%$ & $56.8 \%$ & $0 \%$ \\
\hline Overall & $34.1 \%$ & $49.1 \%$ & $2.5 \%$ \\
\hline
\end{tabular}


Due to the small size of sub-groups across industries, only the industries that have more than 20 respondents are discussed here. Subjective over-education in education is substantially below average, but graduates working in the import/export, wholesale and retail industry have substantially higher subjective over-education ratio. This is a rare case that subjective over-education is higher than objective over-education.

Overall differences across different industries for subjective over-education $(p=0.018)$ are significant. When multiple comparisons are done among industries, it is found that graduates working in education are significantly different from administrative and support $(p=0.022)$, financial and insurance $(p=0.028)$, import/export, wholesale and retail trades $(p=0.003)$, public administration $(p=0.003)$, and transportation, storage, postal and courier services $(p=0.032)$, and other industries $(p=0.029)$. Public administration is significantly different from financial and insurance $(p=0.026)$, human health and social work $(p=0.013)$, information and communication $(p=0.013)$, professional, scientific and technical $(p=0.004)$, real estate activities $(p=0.012)$, and other industries $(p=0.027)$.

Due to small numbers of respondents, including in the comparisons of accommodation and food services (3 respondents), public administration (3 respondents), extraterritorial organizations and bodies (1 respondent), and agriculture, forestry and fishing (1 respondent) industries is not very meaningful.

Subjective over-education, objective over-education and objective under-education between genders are given in Table 6 below:

Table 6: Subjective-Objective Over-/under-Education Between Genders

\begin{tabular}{|l|c|c|c|}
\hline Gender & Subjective OE & Objective OE & Objective UE \\
\hline Female & $32.8 \%$ & $48.8 \%$ & $3.2 \%$ \\
\hline Male & $36.0 \%$ & $49.6 \%$ & $2.2 \%$ \\
\hline Overall & $34.1 \%$ & $49.1 \%$ & $2.5 \%$ \\
\hline
\end{tabular}

Differences in subjective $(p=0.590)$ and objective $(p=0.782)$ over-education between genders are both statistically insignificant.

\section{CONCLUSION}

The subjective over-education is estimated at between 28.54 and 39.66 percent; the objective over-education is estimated at between 43.23 and 54.97 percent. The former is more important than the latter because it can create job dissatisfaction and negative sentiments. Over-education in Hong Kong appears to be more severe than European countries, but it is similar to Japan.

Differences across demographic factors are insignificant except for industries. It appears that there are patterns of over-education. First, professionally-driven majors 
tend to feel less over-educated. Second, over-education tends to peak at Bachelor's degree level; having more or less lowers the feeling of over-educated. Third, as the years of work experience and income level increase, over-education is reduced. Fourth, people in education have a significantly lower subjective over-education.

Over-education can be due to the following reasons. First, major-job mismatch. Graduates are unable to find major-related job so that they accept lower level jobs. In Hong Kong, less than 50 percent of working graduates find their jobs are over 50 percent relevant to their major ( $\mathrm{Li}$, Tsang, Yeung, \& Li, 2017). Second, fresh graduates without relevant work experience tend to accept lower level jobs (Frei \& Sousa-Poza, 2012). Third, graduates enter the labor force at economic downturns. Graduates either accept lower level jobs or go for more education (Pascual Saez, Gonzalez-Prieto, \& CantareroPrieto, 2016). Fourth, variations in the quality of degree-granting institutes. There is heterogeneity of skills among degrees (Storen and Arnesen, 2016; Verhaest and Van der Velden, 2013). Fifth, information asymmetries and institutional characteristics of the labor market (Bender \& Heywood, 2011). Students do not have perfect information about the labor market. They might have thought that there was strong demand in a particular industry or profession, but by the time they graduate, the demand has already been filled. Sixth, government subsidizing education may also produce more graduates than the labor market needs (Freeman, 1976).

There are different reasons for people seeking more education. First, there is wage premium. People on average earn more with higher academic qualification (Legislative Council Secretariat, 2015; Li, Malvin \& Simonson, 2015). Second, there is a higher chance to be invited for a job interview (Shen \& Kuhn, 2012). Third, people who believe higher education prepares them for a better future go for more education. Fourth, people seek more education for their self-interest. Fifth, higher education signals smarter (Borjas, 2016).

There are strong reasons for governments to subsidize education as it generates different external benefits to society. As the Education Bureau (2015) indicates, these external benefits include tax contribution, reducing social welfare payments, reducing crime rate, and a healthier society. However, due to the job-qualification mismatch problem, the government may wish to review subsidizing the types of degree programs in order to address labor market needs.

In a nutshell, with the over-education situation in Hong Kong, students must really think twice whether they should go for an academic degree, a graduate degree or a vocational job-training program. They must clearly define the purpose of their pursuit for more education, whether it is for career or self-interest. If more education is intended for career, students must choose very carefully what to study. If graduates are able to find qualification-matching jobs, dissatisfaction from job, burden of the economic cost incurred from obtaining higher education, grievance towards the government and society should be reduced.

A major short-coming of this pilot study is the small sample size. A larger sample size with sufficient respondents from each major and industries will provide a more reliable result. Furthermore, differences between graduates of government-funded and private institutes should be studied due to its substantial implication on public spending. 


\section{REFERENCES}

Babcock, P. (2010). Real Costs of Nominal Grade Inflation? New Evidence from Student Course Evaluations. Economic Inquiry, 48(4), 983-996. https://doi.org/10.1111/j.1465-7295.2009.00245.x

Bender, K., \& Heywood, J. (2011). Educational mismatch and the careers of scientists. Education Economics, 19(3), 253-274.

Borjas, G.J. (2016). Labor Economics, $7^{\text {th }}$ Edition, McGraw Hill.

Caroleo, F., \& Pastore, F. (2015). Overeducation: A Disease of the School-to-Work Transition System. IZA Discussion Papers.

Census and Statistics Department. (2013). Hong Kong Poverty Situation Report 2012. Government of the Hong Kong Special Administrative Region. Table A.3.12. P. 133

Census and Statistics Department. (2017). Hong Kong Poverty Situation Report 2016. Government of the Hong Kong Special Administrative Region. Table A.3.13. P. 182

Chevalier, A., \& Lindley, J. (2008). Over-Education and the Skills of UK Graduates. Journal of the Royal Statistical Society, 1-46.

Davos-Klosters. (2014). Matching Skills and Labour Market Needs, Building Social Partnerships for Better Skills and Better Jobs. World Economic Forum, Global Agenda Council on Employment.

Duncan, G., \& Hoffman, S. (1981). The incidence and wage effects of overeducation. Economics of Education Review, 1(1), 75-86. https://doi.org/10.1016/0272-7757(81)90028-5

Education Bureau. (2015). Resource Pack for the Economics Curriculum (Secondary 4-6), Economic Analysis and Evaluation of Government Policies. Personal, Social and Humanities Education Section, Curriculum Development Institute, Education Bureau.

Education Bureau. (2016). Government Expenditure on Education. The Government of the Hong Kong Special Administrative Region.

Education Bureau. (2017, November 16). iPASS. Retrieved from http://www.ipass.gov.hk/edb/index.php/en/home/statheader/stat/stat_pg_index

Frank, R., Bernanke, B., \& Antonovics, K. H. (2017). Principles of Economics. McGraw Hill.

Freeman, R. (1976). The over-educated American. New York: Academic Press.

Frei, C. \& Sousa-Poza, A. (2012). Overqualification: permanent or transitory? Applied Economics, 44, 1837-1847. https://doi.org/10.1080/00036846.2011.554380

Henderson, R. (2011). English Education and the Great Grade Inflation Fraud. England calling. http://englandcalling.wordpress.com/2011/01/12/english-education-and-the-great-grade-inflationfraud.

Kariya, T. (2011). Credential inflation and employment in 'universal' higher education: enrolment, expansion and (in)equity via privatization in Japan. Journal of Education and Work, 24(1-2), 69-94. https://doi.org/10.1080/13639080.2010.534444

Kucel, A., Molina, I.F., \& Raya, J.M. (2016). Over-education and its opportunity cost in Japan. Asia Pacific Education Review, 17(2), 299-312. https://doi.org/10.1007/s12564-016-9427-8

Kuhn, J., Warren, A., Maletta, D., \& Branford, A. (2011). Local Grade Inflation and Local Proportion of Withdrawals. Research in Higher Education Journal, 14, 1-33.

Legislative Council Secretariat. (2015). Social mobility in Hong Kong. Research Brief, Issue No. 2, 2014- 
2015.

Legislative Council Secretariat. (2016). Challenges of manpower adjustment in Hong Kong. Research Brief, Issue No. 4, 2015-2016.

Li, I., Malvin, M., \& Simonson, R. (2015). Overeducation and Employment Mismatch: Wage Penalties for College Degrees in Business. Journal of Education for Business, 119-125. https://doi.org/10.1080/08832323.2014.988204

Li, T. (2015). Required graduate attributes in Hong Kong and their relative importance. European Scientific Journal, 11(34), 536-561.

Li, T., Tsang, M., Yeung, M., \& Li, E. (2017). An estimate of major-job relevancy and the relative importance of professional skills in the workplace in Hong Kong. International Journal of Teaching and Education. https://doi.org/10.20472/TE.2017.5.1.004

Linda, D. A., Marchal, W., \& Wathen, S. (2018). Statistical Techniques in Business \& Economics (17th ed.). McGraw-Hill International Edition.

Marginson, S. (2017 in press). Higher education, economic inequality and social mobility: Implications for emerging East Asia. International Journal of Educational Development. http://dx.doi.org/10.1016/j.ijedudev.2017.03.002

Mok, K. H. (2016). Massification of higher education, graduate employment and social mobility in the Greater China region. British Journal of Sociology of Education, 37:1, 51-71. https://doi.org/10.1080/01425692.2015.1111751

Mok, M. (2007). Quality assurance and school monitoring in Hong Kong. Education Research Policy Practice, 6, 187-204. https://doi.org/10.1007/s10671-007-9027-9

Pascual Saez, M., Gonzalez-Prieto, N., \& Cantarero-Prieto, D. (2016). Is Over-Education a Problem in Spain? Empirical Evidence Based on the EU-SILO. Social Indicators Research, 617-632. https://doi.org/10.1007/s11205-015-0916-7

Quintini, G. (2011). Over-qualified or under-skilled: A review of existing literature. Organisation for Economic Co-operation and Development, Directorate for Employment, Labour and Social Affairs. https://doi.org/10.1787/5kg58j9d7b6d-en

Robst, J. (1995). College quality and overeducation. Economics of Education Review, 14(3), 221-228. https://doi.org/10.1016/0272-7757(94)00054-A

Rubb, S. (2003). Overeducation: a short or long run phenomenon for individuals? Economics of Education Review, 22, 389-394. https://doi.org/10.1016/S0272-7757(02)00052-3

Sadler, D.R. (2009). Grade Integrity and the Representation of Academic Achievement. Studies in Higher Education, 34(7), 807-826. https://doi.org/10.1080/03075070802706553

Shen, K. \& Kuhn, P. (2012). Do Chinese Employers Avoid Hiring Overqualified Workers? Evidence from an Internet Job Board. IZA (Institute for the Study of Labor) Discussion Paper No. 6848.

Smith, D.E., \& Fleisher, S. (2011). The Implications of Grade Inflation: Faculty Integrity versus the Pressure to Succeed. Journal of Research in Innovative Teaching, 4(1), 32-38.

Storen, L.A., \& Arnesen, C.A. (2016). Skills utilisation at work, the quality of the study programme and fields of study. Quality in Higher Education, 22(2), 127-138. https://doi.org/10.1080/13538322.2016.1195968

Tung, C. H. (2000). Chief Executive's Policy Address 2000. Hong Kong Government Printer. 
University Grant Committee of Hong Kong. (2010). Aspirations for the Higher Education System in Hong Kong, Report of the University Grants Committee.

Vance, J. (2014). The College Trap: Our higher-education system hurts the poor. National Review, 3132.

Verhaest, D., \& Van der Velden, R. (2013). Cross-country Differences in Graduate Overeducation. European Sociological Review, 29(3), 642-653. https://doi.org/10.1093/esr/jcs044

Vermeylen, G., \& Giuliano, R. (2014). Educational Mismatch and Employment Contracts: A Labour Productivity Analysis. International Advances in Economic Research, pp. 469-470. https://doi.org/10.1007/s11294-014-9485-9

Wan, C. (2011). Reforming higher education in Hong Kong towards post-massification: the first decade and challenges ahead. Journal of Higher Education Policy and Management, 33(2), 115-129. https://doi.org/10.1080/1360080X.2011.550034

Zhu, R. (2014). The impact of major-job mismatch on college graduates' early career earnings: evidence from China. Education Economics, 22(5), 511-528. https://doi.org/10.1080/09645292.2012.659009 